\title{
The association between board gender diversity and financial reporting quality, corporate performance and corporate social responsibility disclosure: A literature review
}

\begin{abstract}
Purpose (mandatory) Companies, politicians, the mass media, legislators, scholars and society in general have shown a growing interest in how board gender diversity affects a firm's decisions. This concept has been developed because some nations have introduced voluntary policies to regulate and increase the proportion of female directors on corporate boards. Thus, the aim of this study is to review previous research based on board gender diversity as a corporate governance mechanism and its effect on some firms' business decisions: Financial reporting quality (FRQ), firm performance and corporate social responsibility (CSR) reporting.
\end{abstract}

Design/methodology/approach (mandatory) We focus on agency and stakeholder theory to examine the link between female directors on boards and financial reporting quality, corporate social responsibility disclosure and firm performance

Findings (mandatory) This review provides researchers a structure that can identify the benefits and disadvantages of including female directors on boards regarding three particular corporate outcomes (FRQ, firm performance and CSR reporting).

\section{Research limitations/implications (if applicable)}




\section{Practical implications (if applicable)}

\section{Social implications (if applicable)}

Originality/value (mandatory) This study provides a review of past literature on firm performance, CSR disclosure and FRQ from 1975 to 2017, and it contributes to past research by giving a broad overview of the main results of the association between female board directors and corporate decisions. The findings have implications for governments, academics and company managers.

Keywords: Corporate governance, gender diversity, boards, firm performance, financial reporting quality, corporate social responsibility disclosure

\section{Introduction}

Researchers, regulators and society in general have paid attention to the evolution of female representation on boards in recent years. All companies wish to have competitive advantage over their competitors so that they can be competitive in markets. In this line, Resource Based View has been defined as the theory of competitive advantage where the resources are important for the firm in order to install them in their product markets. The incorporation of men and women are considered an important human resource in firms since their differing talents are important in positions of responsibility. Terjesen et al. (2008) posit that the expertise and reputation of board members may drive to improve firms' benefits. 
Concerning the presence of female directors on boards, Solimene et al. (2017) examined the Milan Stock Exchange and confirmed an increase in the number of women directors on boards from $6.61 \%$ in 2009 to $22.69 \%$ in 2014. In the Spanish and Latin American contexts, the tendency is also one of increased board gender diversity, but this increase is lower. Terjesen et al. (2016) argue that the proportion of female directors on corporate boards in Portugal was $3.8 \%$ in 2016, while considering that Spain is one of the eight first countries where the proportion of women directors on boards is greater than $10 \%$. In this sense, in 2014, Heidrick and Struggles' Report shows that the proportion of women directors on boards in Spain increased from $9 \%$ in 2001 to $13 \%$ in 2013. In Latin America, boards of the big 100 firms in the region are made up by $93.60 \%$ men (ILO, 2015, 2017). Additionally, the Corporate Women Directors International Report 2015 reports that the percentage of female directors on boards was, for example, $6 \%$ in Peru, $5.1 \%$ in Mexico and $3.2 \%$ in Chile. There is scant research (CEPAL, 2016; Flabbi et al., 2016) focusing on the presence of female directors on Latin American boards, which argues that board gender diversity in the region is in transition. According to the OIT (2015), there are a lot of mentions of "male chauvinism" and its impact on gender differences. Corporate culture in many firms of Latin America maintains the gender stereotypes of the Latin culture, which may explain the low presence of female directors on boards. However, women are taking advantage of the opportunities that education provides them to advance in economic and political positions. In contrast, Thair (2017) highlights that $90 \%$ of the New Zealand Stock Exchange firms do not have any female directors on their boards. Past research (e.g., Morrison et al., 1987; Arfken et al., 2004; Dang et al., 2014) argues that the lack of female directors on boards may be caused by the glass ceiling, an invisible barrier that hinders the rise of women in firms (Morrison et al., 1987). Mateos de Cabo (2017) states that in Spain, the barriers that delimit the access of female directors to corporate boards come from both the offer and the demand. The barriers from the 
offer side are: (1) differences in values and attitudes, (2) the identification of cultural and social roles, and (3) work-family conflicts. Those from the demand side are: (1) bias in the selection process, (2) wrong perceptions of the contribution of women as directors, and (3) the institutional context. In general terms, the existence of barriers in Portugal and Latin America are similar (Elvira and Dávila, 2005).

The current worldwide financial crisis and a succession of financial scandals question the role of managers and CEOs, focusing the attention on different areas such as corporate governance, corporate social responsibility (CSR) and board composition, with board gender diversity being a main issue of debate. According to Seierstad (2016), the role of female directors on boards is very important for two reasons: (1) the business case, and (2) the justice case. The first is based on the premise that the incorporation of female directors on boards achieves new abilities, which may improve business performance. The second focuses on the need to establish heterogeneity on corporate boards in order to have the same representation of all individuals on the teams. In line with this, this paper is based on the first case, because we consider that women directors on boards may provide different points of view in decisionmaking processes when compared to men, which can be very beneficial for business (Hoobler et al., 2016). We have based this paper on agency and stakeholder perspectives.

Thus, the main goal of this study is to review past literature focused on the influence of female board directors on financial reporting quality (FRQ), firm performance and CSR disclosure. Interest in these areas has increased in recent years due to the financial crisis and financial scandals. In order to conduct an extensive and detailed review, we examine academic journals at both national and international levels. This paper could help readers to understand the influence of board gender diversity on some organizational outcomes from agency and stakeholder perspectives and their implications for corporate governance matters. This review provides researchers with a structure that can identify the benefits and 
disadvantages of including female directors on boards regarding three particular corporate outcomes (FRQ, firm performance and CSR reporting).

The remainder of this paper is structured as follows. In the next section, we explain the methodology used in this literature review. In Section Three, we describe the business case for female directors on corporate boards, while Section Four outlines the female leadership style. In Section Five, we offer a review of prior research into how female directors on boards affect financial reporting quality, CSR disclosure and firm performance from agency and stakeholder perspectives. Finally, in Section Six, we draw the conclusions.

\section{Methodology}

This paper provides a literature review of the effect of female board directors on FRQ, firm performance and CSR disclosure (Weber, 1990; Newbert, 2007). The process used is the selection of articles from academic journals published during the 1975 to 2017 period. In the first phase, we collected the papers available in the following databases: ABI/INFORM Complete, Google Scholar, Elsevier, Emerald, Springer Link and Wiley-Blackwell, seeking for in the abstract or the title several key words such as "female directors", "corporate boards", "business case", "firm performance", "CSR disclosure", "agency theory" and "stakeholder theory", among others. The corporate governance literature comprises a lot of papers on the role performed by women board directors; however, not all of them have been selected. In the second round, we have selected the most relevant papers by examining their content. In this sense, we have read all articles fully and identified the discussion linked to the influence of female board directors on FRQ, firm performance and CSR disclosure. Moreover, we considered the most important articles based on sociological, cognitive and psychological perspectives. The main academic journals used in this paper are the following: Accounting Horizons (2), Journal of Financial Economics (3), Management Science (1), 
Harvard Business Review (3), The Quarterly Journal of Economics (1), Estudios Gerenciales (1), Journal of Accounting and Public Policy (2), Journal of Business Ethics (19), Journal of Management and Governance (2), Sex Roles (2), Women on Corporate Boards of Directors (1), Entrepreneurship: Theory and Practice (1), Personality and Social Psychology Bulletin (1), Psychological Bulletin (1), Corporate Governance: An International Review (7), The Financial Review (2), Academy of Management Journal (3), The Accounting Review (1), Work and Occupations (1), Journal of Applied Business Research (3), Cross cultural management: An international journal (1), Corporate Social Responsibility and Environmental Management (7), Journal of Management Studies (1), Group and Organization Management (1), Journal of Business Finance \& Accounting (1), International Journal of Accounting and Financial Reporting (1), Hasting Female's Law Journal (1), Journal of Management (2), Business \& Society (1), Academy of Management Review (1), Women in Management Review (1), Quarterly Journal of Finance and Accounting (1), Economic Inquiry (1), Organization (1), Journal of Management and Sustainability (1), Gender in Management: An International Journal (2), Business Ethics: A European Review (2), Journal of Corporate Finance (2), Pacific-Basin Finance Journal (1), Contemporary Accounting Research (2), Journal of Management \& Governance (2), African Journal of Business Management (1), Pakistan Journal of Gender Studies (1), American Economic Journal: Applied Economics (1), Human Relations (1), Journal of Business Research (1), Strategic Management Journal (1), Industrial and Corporate Change (1), Meditari Accountancy Research (1), The Academy of Management Executive (1), European Journal of Law and Economics (1), Directors and Boards (1), Springer International Publishing (1), Asian Journal of Business Ethics (1), Frontiers of Business Research in China (1). Figure 1 summarizes the main ideas of this study. 


\title{
Figure 1
}

\section{Board Gender Diversity Framework}

\author{
Agency Theory
}

Women control board activities and reduce information asymmetries

FRQ

\section{Psychological \\ Perspectives}

Female leadership style is democratic, proactive and unique

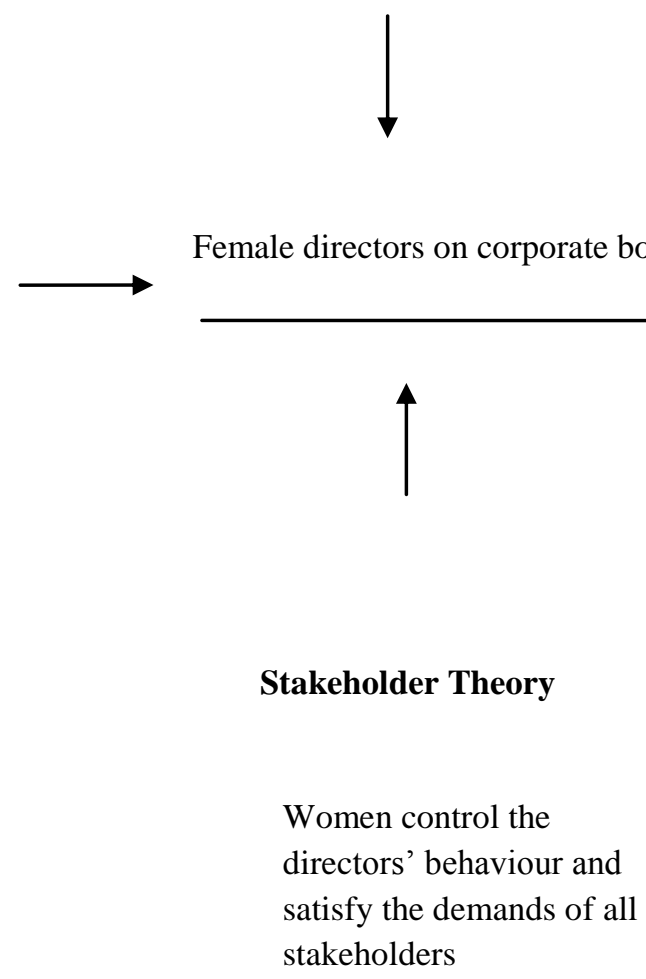

CSR

disclosure

Firm performance

\section{Business Case for Female Directors on Corporate Boards}

In the 1980s, the scant presence of women and ethnic minorities in the US workforce were considered a management problem (Johnston and Packer, 1987). Nevertheless, this changed when companies supported the "managing diversity" business case, where female directors were considered to have abilities that could improve economic efficiency and guarantee competitive advantage (Johnson, 2006).

Several scholars have examined female board directors through the business case for diversity (Bilimoria, 2000; Terjesen et al., 2009; Seierstad, 2016). This view defends the idea 
that female board directors have the skills to be better directors than men and, as a consequence, their presence on boards drives higher organisational performance in several ways. First, board diversity helps in understanding the volatility of the labour market because it leads to a wider range of demographic perspectives for penetrating markets and attracting potential customers and suppliers (Robinson and Dechant, 1997). Second, women board directors create an open and relaxed atmosphere (Huse and Solberg, 2006) and improve innovation and creativity, providing a rich source of innovative ideas. Third, the inclusion of female directors helps solve firms' problems by creating board heterogeneity in the decisionmaking process, which forces companies to evaluate more alternatives and more carefully consider their consequences (Carter et al., 2003). Therefore, the business case for board gender diversity is part of the corporate governance field, since the inclusion of female directors on corporate boards may lead to internal and external business benefits.

\section{Female leadership style}

Leadership is defined as the ability to influence aptitudes, attitudes, and beliefs in order to achieve a firm's most relevant goals (Maleki and Askari, 2013). Several authors, such as Chapman (1975) and Manzoor and Abrar (2011), among others, have compared male and female leadership styles. Female leadership style is characterized by leaders who are more caring, sensitive and sympathetic, which implies that they are more proactive in cooperating, while male leaders are more autocratic, dominant, self-confident and, as a consequence, more competitive (Eagly and Carli, 2007; Kim, 2013). Women have a more democratic leadership style in the decision-making process than males, as well as greater dedication towards employees (Bird and Brush, 2002), and their leadership is orientated towards interpersonal relationships (Melero, 2011). In line with this, females have developed a series of behaviours, values and interests that create a unique leadership style (Rosener, 1990). Thus, female 
leadership is considered a critical and key determinant for organisations' success (Eagly and Carli, 2003). According to Barbuto et al. (2007) and Davis et al. (2010), females use their leadership style in order to maintain higher motivation among a firm's employees. Nielsen and Huse (2010) and Matsa and Miller (2013) demonstrated that female directors have a different leadership style than males, since they may act with greater sensitivity and attentiveness to stakeholders' needs and, therefore, their leadership style is more effective in the business context (Eagly and Carli, 2003). In line with this, Evans (2010) reported that females are emotionally more intelligent, since they can control their emotions and can work in complex scenarios. Thus, women have abilities such as active listening, communication, empathy and multi-tasking (Evans, 2010), which allow them to achieve management team cohesion in the decision-making process.

Consistent with sociological, cognitive and psychological approaches, female directors may affect relevant corporate decisions and other aspects of corporate governance. Existing empirical evidence shows that female directors have a more adverse attitude towards risk (Jianakopolos and Bernasek 1998; Byrnes et al., 1999; Thiruvadi and Huang, 2011; Man and Wong, 2013), so they are more conservative (Zhou, 2012) and demonstrate more prudent behaviour than males when making important corporate decisions (Huang and Kisgen, 2013; Levi et al., 2014). In addition, female directors may quickly detect opportunistic behaviour (Khazanchi, 1995; Ruegger and King, 1992), because they are stricter supervisors and demand more audit efforts than male directors (Adams and Ferreira, 2009; Gul et al., 2008). These ethics and greater social abilities allow them to align the interests of shareholders and, as a consequence, to participate in and decide on the most important corporate decisions. Hence, the female leadership style may differ from the male leadership style and, consequently, may have a different impact on business decisions. 
Female leadership style is more social and ethical than the male leadership style and, therefore, the inclusion of female directors on corporate boards may help in making relevant decisions in companies, since they show a more responsible, more civilized, stricter and more conservative attitude than their male counterparts.

\section{Theoretical Approaches to Female Directors on Corporate Boards}

The academic community has shown a growing interest in the incorporation of females to boardroom positions and their significant role in firms (Huse and Solberg, 2006; Torchia et al., 2011). This paper focuses on agency and stakeholder theory to develop a theoretical framework that will help in understanding the influence of women board directors on FRQ, firm performance and CSR disclosure. We focus on these three firm outcomes because of the growing attention that they are receiving from firms, shareholders, potential investors and others due to the financial crisis and financial scandals. Kirsch (2017) has carried out a systematic review on the features shaping board gender composition and on what effect board gender composition has on organisational outcomes. Further, the author also tries to answer why regulatory bodies establish quotas and other measures in order to have women's representation on boards and what it is expected from these mechanisms.

\section{Agency theory}

Agency theory postulates that the disparity of interests between managers and owners may give rise to informative asymmetries between the parties because owners tend to delegate their responsibilities to managers to make strategic decisions on their behalf, causing agency problems (Jensen and Meckling, 1976). In line with this, shareholders may demand more control mechanisms for monitoring managers to reduce agency costs, such as external audits 
(Anderson et al., 1993) and CSR disclosure (Harjoto and Jo, 2011; Martínez-Ferrero et al., 2015), among others.

In this sense, agency theory presumes that female directors may act as a mechanism of supervision and control of a board's activities (Adams and Ferreira, 2009; Francoeur et al., 2008; Huse and Solberg, 2006), mitigating agency costs and information asymmetries (Carter et al., 2003; Adams and Ferreira, 2009; Wellalage and Locke, 2013), since their presence on corporate boards increases board independence (Carter et al., 2010; Reguera-Alvarado et al., 2015). One argument which may explain this premise is that more diverse boards with nontraditional characteristics may raise questions that would not come from senior directors on boards. Female directors have acquired high levels of education, such as master's and other postgraduate degrees and, therefore, are considered highly professional and experienced (Solimene et al., 2017) in making important decisions on boards. These empirical findings suggest that the incorporation of females into boardrooms affects executive compensation (Lucas-Pérez et al., 2015), dividend policy (Pucheta-Martínez and Bel-Oms, 2016), firm value (Kılıç and Kuzey, 2016; Pucheta-Martínez et al., 2016b; Terjesen et al., 2016), FRQ (Clatworthy and Peel, 2013; Pucheta-Martínez et al., 2016a) and CSR disclosure (Rao and Tilt, 2015; Liao et al., 2016), among others.

Agency theory is one of the crucial theories used by scholars to discuss the effect of board gender diversity on firm performance. This theory postulates that female board directors bring a wider range of perspectives, which increases board independence while also reducing agency costs and, as a consequence, increasing firm value (Hillman and Dalziel, 2003). The inclusion of female board directors with high responsibility in the decisionmaking process (Adler, 2001; Adams and Ferreira, 2003; Carter et al., 2003; Jimeno and Redondo, 2008; Campbell and Minguez-Vera, 2008) increases firm performance, since they improve the decision-making capacity (Erhardt et al., 2003), which, in turn, becomes a 
competitive advantage (Burke, 1997; Campbell and Minguez-Vera, 2008). This idea is supported by Terjesen et al. (2009). However, earlier studies demonstrated that the influence of female directors on firm performance is inconclusive. Some authors find a positive association between female directors and firm value (Liu et al., 2014; Gyapong et al., 2016; Kilıç and Kuzey, 2016; Terjesen et al., 2016), since they control the board's functions (Adams and Ferreira, 2009; Francoeur et al., 2008; Huse and Solberg, 2006; Schwartz-Ziv, 2011) and play an effective role of monitoring managers (Khazanchi, 1995; Ruegger and King, 1992) and, as a result, may enhance corporate value. Additionally, the inclusion of female directors on corporate boards may affect corporate decisions, reducing the bids premium and, ultimately, creating shareholder value (Levi et al., 2014) and enhancing integration and communication (Maznevski, 1994). Contrary to this evidence, other authors (Adams and Ferreira, 2009; Ahern and Dittmar, 2012) demonstrated that there is a negative association between board gender diversity and corporate performance. This is due to regulations and recommendations forcing, or suggesting that, firms hire female directors on boards and, as a result, females may have less experience in these matters. In line with this, Dong (2014) reported that female investors are less sensitive to financial operations and, therefore, could reduce firm value.

Furthermore, authors such as Frink et al. (2003) show an inverted U-shaped association between women directors and firm value - that is, female directors have a positive influence on firm performance, but beyond an inflection point, the addition of more female directors on boards has a negative effect on firm performance. This finding suggests that the optimal number of female directors is near the midpoint, supporting the monitoring and entrenchment hypotheses. Pucheta et al. (2016b) found that female institutional directors on boards enhance firm value, but when their presence exceeds a certain threshold, firm performance decreases. These results support the view that institutional women directors 
perform an active role in monitoring managerial behaviour, according to the supervision (monitoring or contest) hypothesis, but when their presence on boards is higher than a certain point, they do not supervise the management team and they align with managers' interests, in line with the collusion (expropriation or entrenchment) hypothesis. The monitoring or contest hypothesis is based on the relationship between managers and shareholders, since the majority of shareholders have an incentive to monitor their managers in order to reduce agency conflicts. On the other hand, the entrenchment or expropriation hypothesis comes into effect when the majority of shareholders use their power to make decisions in favour of their own interests, which may negatively affect minority shareholders. These results are consistent with the theory proposed by Brewer (1991). He postulates that the impact of board composition might be non-lineal, since extreme proportions (very high and low) in demographic characteristics such as gender diversity on boards drive negative effects, while balanced proportions lead to positive effects. Nevertheless, Joecks et al. (2013) demonstrated that women board directors have a negative impact on firm value, but when the proportion of women reaches $30 \%$, the effect on firm value is positive.

In accordance with agency theory, in order to develop adequate supervisory functions, board members need the ability and experience to evaluate business strategies and their influence on CSR reporting (Hillman and Dalziel, 2003). Companies that voluntarily report CSR information in their annual sustainability reports are considered more socially responsible and may improve relationships with bankers, investors, customers, suppliers, and competitors and, ultimately, they may mitigate agency problems. Research based on CSR reporting has paid little attention to the association between board gender diversity and CSR disclosure. In this vein, past literature (Alonso-Almeida et al., 2015) documented that female leadership style encourages CSR practices, with women directors considered drivers of CSR activities (Harjoto et al., 2015; Setó-Pamies, 2015; Landry et al., 2016). In line with this, 
female directors may be more sensitive to CSR activities than males, since they have more inclination to education, regulations, and non-profit activities (Harrigan, 1981; Kesner, 1988; Stultz, 1979; Bear et al., 2010). The inclusion of more than two females on corporate boards may align the interests of shareholders, since they may persuade board members to establish voluntary CSR assurance (Liao et al., 2016), as they are considered more benevolent than their male counterparts (Adams and Funk, 2012). However, the association between women directors and CSR reporting may be negative, and this may be a consequence of female directors' lack of education and expertise (Muttakin et al., 2015). Additionally, PuchetaMartínez and Bel-Oms (2017) show an inverted U-shape relationship between external women directors (independent and institutional) and CSR disclosure, since the inclusion of female directors on corporate boards improves CSR disclosure, in line with the monitoring hypothesis, but when their presence on boards reaches a turning point, CSR reporting decreases, consistent with the expropriation hypothesis. Overall, the inclusion of female directors on boards tends to affect CSR disclosure, although the contributions and repercussions depend on the theoretical approach used.

From an agency perspective, it is generally agreed that companies should disclose financial statements with clarity, relevance, reliability, and transparency (Jonas and Blanchet, 2000; Lu et al., 2011) in order to mitigate asymmetric information (Chen et al., 2011) and agency costs. The existence of information asymmetries between parties may lead to managers having more internal company knowledge than the owners, which they can use for their own benefit. If firms do not have information asymmetries, managers and owners have equal knowledge of the company and can reach agreement in terms of business decisions. So, financial reporting quality (FRQ) is defined as a process that depends on the commitment that each firm assumes in disclosing financial information. In this sense, board composition is a key factor in assuring the transparency and credibility of financial statements, and the 
inclusion of women directors on boards may improve FRQ, since they behave more ethically than male directors and may identify opportunistic behaviours in companies (Khazanchi, 1995; Ruegger and King, 1992).

Thus, female directors on boards may improve monitoring activities (Adams and Ferreira, 2009; Huse et al., 2009) and, as a consequence, may increase FRQ (PuchetaMartínez et al., 2016a). Female directors on corporate boards reduce the probability of disclosing financial information with errors (Ittonen et al., 2010) or of manipulating financial statements (Heminway, 2007). They therefore improve investors' confidence in firms' financial statements (Srinidhi et al., 2011). In line with this, Gulzar and Wang (2011) and Schwartz-Ziv (2011) reported that directorship gender diversity reduces management earnings, resulting in enhanced FRQ, and Clatworthy and Peel (2013) showed the effect of female directors on the accuracy of financial information. Additionally, other studies focused on how the proportion of female directors on boards impacts on FRQ. Authors such as Gul et al. (2008), Schwartz-Ziv (2011) and Abbott et al. (2012) provided evidence that a greater number of women in boardrooms improved the quality of financial information, since they increased the supervision of financial statements. Furthermore, when corporate boards are chaired by women, financial information is more meticulously supervised than when boards are chaired by males (Schwartz-Ziv, 2011), consequently, improving earnings quality (Peng, 2007; Pucheta-Martínez et al., 2016a). One explanation of the effect of female directors on FRQ might be due to the female leadership style, which is considered more responsible for a firm's decisions than male leadership style (Heminway, 2007; Thiruvadi and Huang, 2011; Zhou, 2012) and, as result, their decisions on FRQ are more conservative than male board members. 


\section{Stakeholder theory}

Stakeholder theory was introduced by Freeman (1984), who argued that managers should take into account the interests of all company stakeholders, not just the shareholders. This author defines stakeholders as "those persons or groups that can affect the achievement of the company's objectives, or that are affected by the achievement of a firm's objectives". The groups that have an interest in a company include shareholders, employees, customers, suppliers, lenders, the government and society. However, it is very difficult, if not impossible, to attend to all stakeholders' interests. Managers should develop relationships, inspire their stakeholders, and create communities where everyone strives to achieve firm value. In line with this, the main role of corporate boards is not only to maximize the value of stakeholders, but also to extend loyalty towards them (Rose, 2004). However, the pressure that companies experience to appoint female directors on boards comes from shareholders, politicians, consumers and institutional investors (Fields and Keys, 2003), among others. In this sense, Dallas (2002) provides evidence that continuous change in the business environment favours the creation of heterogeneous groups, since these may enhance creativity, the quality of decision-making and the rise of diverse perspectives, despite the possibility that a homogeneous group may improve communication and coordination. The integration of minority groups on boards, such as the presence of women, can indicate the commitment of firms to stakeholders (Francoeur et al., 2008; Webb, 2004). In this way, a heterogeneous group may control the directors' behaviour and may satisfy the demands of different stakeholders, since gender diversity may bring diverse perspectives and encourage efficient overseeing of boards (Jimeno and Redondo, 2008). For this reason, the incorporation of female directors on corporate boards may benefit relationships among stakeholders.

Stakeholder theory can help managers to determine where their attention is needed to create firm value. Based on this theory, we review past research on the influence of corporate 
governance gender diversity on firm performance. In general terms, the appointment of females to boards has an indeterminate influence on firm performance. Several studies indicate that female directors on corporate boards have a positive influence on firm performance (Lückerath-Rovers, 2013; Low et al., 2015), since the incorporation of female directors on boards may improve connections among all stakeholders at all levels of the firm, enhancing the a company's reputation and, at the same time, increasing corporate value (Lückerath-Rovers, 2013). Another important stream of research explores the negative influence of female directors on firm performance (Van Ees et al., 2007; Abdullah et al., 2013). This effect is explained by the behaviour of female directors on boards, since their main interests are focused on improving a firm's social responsibility, instead of increasing firm performance. Finally, Rose (2007) finds no association between female directors and firm performance, since non-conventional board members adopt conventional behaviours. For this reason, the socialisation process in board composition has been removed.

Stakeholder theory also postulates that female directors on boards allow firms to become more innovative, transparent and modern, therefore preparing companies for changes in CSR legislation, which in turn will have a positive influence on firms' financial performance. CSR disclosure is based on stakeholder theory. An influential argument from this perspective is related with the role of firm managers. Managers have to satisfy company stakeholders with significant influence on firm success, and this allows them to garner support for CSR issues (Fernandez-Feijoo et al., 2014; Larrieta-Rubín de Celis et al., 2015; Kaspereit et al., 2016). In addition, the inclusion of female directors on corporate boards may be considered an indicator of CSR for companies and a signal of being geared towards stakeholders (Oakley, 2000; Ibrahim and Angelidis, 1994; Webb, 2004). Fernandez-Feijoo et al. (2014), Harjoto and Jo (2015), Harjoto et al. (2015), Rao and Tilt (2016) and Yasser et al. (2017) documented that female directors have the potential to influence CSR reporting. In line 
with this, Hillman et al. (2002) argued that a high proportion of female directors on boards allows companies to govern more openly, guaranteeing that stakeholders' interests are met. Larrieta-Rubín de Celis et al. (2015) found that female directors apply specific initiatives to obtain more democratic and socially and environmentally committed firms, which enhances CSR practices. In addition, female directors act more responsibly, according to cognitive, psychological and sociological literature and, therefore, may encourage firms to disclose CSR information. On the other hand, Hsu and Cheng (2012) argued that there is no relationship between female directors and a willingness to engage in CSR practices, and Muttakin et al. (2015) showed that female directors have a negative effect on CSR disclosure in familyowned firms, as they may be orientated in line with family issues instead of business affairs, because they do not have business abilities and experiences.

Firms' managers may manipulate financial information to achieve personal benefits, damaging the interests of shareholders and the other stakeholders (Prior et al., 2008). In line with this, stakeholder theory argues the importance of companies conducting external audits and corporate governance actions in order to monitor the interests of stakeholders and to avoid management earnings practices, which may improve financial reporting quality. This implies that the presence of women in positions of responsibility is an essential factor in the corporate governance structure, since female directors may attend to the needs of all stakeholders and, therefore, help firms understand stakeholders' relationships (Hillman et al., 2001). Female directors might provide diverse perspectives (Jimeno and Redondo, 2008), emphasising responsible and responsive opinions. This implies that their presence on corporate boards may avoid management earnings, thus increasing the quality of financial reporting and, ultimately, defending and improving the interests of all stakeholders. Barako and Brown (2008), Prado-Lorenzo and García-Sánchez (2010) and Frias-Aceituno et al. (2013) provide evidence that the presence of women on a corporate board increases the level 
of a firm's disclosure and its quality, since female directors are more conservative. Dobija et al. (2016) and Pucheta-Martinez et al. (2016a) documented that female board directors increase the quality of financial information and benefit the interests of all stakeholders, since the decisions on financial reporting practices are more conservative.

\section{Conclusions}

This study provides a review of past literature on firm performance, CSR disclosure and FRQ from 1975 to 2017, and it contributes to past research by giving a broad overview of the main results of the association between female board directors and corporate decisions. Both agency and stakeholder theories claim the importance of including women directors on boards in order to make financial and non-financial decisions, such as mitigating agency costs or increasing commitment between firms and all stakeholders. The business case helps us understand the consequences of the inclusion of female directors on boards in recent years. Furthermore, female leadership style is essential in companies' decision-making processes, since female directors improve FRQ and return confidence and reliability to investors, suppliers, customers and society in general. Additionally, according to previous research female board directors are more inclined to focus on education, regulations, and non-profit activities and, as a consequence, they may encourage the voluntary disclosure of CSR information through their ability to persuade board members to establish voluntary CSR practices. Moreover, female directors may improve the connections between all stakeholders at all levels of the firm, influencing corporate decisions and, ultimately, improving firm performance. However, we have observed that the establishment of mandatory gender quotas in firms may have a negative or positive impact on their output, because there are some external factors, such as the financial crisis, corporate governance structure, financial scandals 
and state intervention, among others, which may modify the presence and influence of gender diversity in firms (Chun, 2013; Gabaldon et al., 2016; Seierstad et al., 2017).

This study has implications for governments, academics and company managers. The government should consider our conclusions in order to make recommendations that promote gender equality on corporate boards, since the review of the literature shows the positive influence of female directors on boards from both an ethical and economic point of view. In particular, given the low presence of women directors on Spanish and Latin American boards, their governments in collaboration with firms and practitioners, should make an effort to act towards the increase of female directors on positions of responsibility; for instance, trying to change some corporate cultures, mitigating or eliminating male chauvinism and raising awareness in society, particularly in firms, that women are as acceptable as men to occupy a post of responsibility. We do not mean to impose gender quotas, but to recommend the presence of female directors on boards, since some countries, such as the UK, Australia and Sweden, have achieved very significant results by improving gender equality on their boards without a mandatory quota. Furthermore, academics should focus their investigations on providing evidence of how female directors may influence business decisions that past research has overlooked and to understand their role on corporate boards. Furthermore, companies should consider the incorporation of female directors on their boards due to the benefits that heterogeneous boards can provide, such as enhancing creativity, improving the quality of the decision-making process and introducing diverse perspectives, among others. Moreover, the female leadership style is unique since female directors are more responsible, civilized, stricter and conservative than their male counterparts, which may improve the business decision-making process. Additionally, the inclusion of female directors on boards also has important implications, according to the theoretical approach used. Female directors reduce agency problems and satisfy the demands of different stakeholders, allowing us to 
understand how board gender diversity affects FRQ, firm performance and CSR reporting. Finally, this literature review provides new ideas and point of views of the specific research focused on the inclusion of female directors on boards and its effects on FRQ, CSR disclosure and firm performance. This research framework can be used for scholars in future research based on board gender diversity and can enable policy makers to encourage gender equality on corporate boards.

This paper proposes further research linking the presence of women on boards with corporate governance indicators, differentiating the typology of female directors on boards. This suggestion should examine the link between independent, institutional and executive female directors and FRQ, firm performance and CSR disclosure, since it will allow us to enrich our knowledge of the complex interaction of female directors, depending on the typology of directors.

\section{Acknowledgements}

We would like to thank the suggestions and useful comments made by two anonymous referees and by the Guest Editor Prof. Ogliastri.

\section{References}

